\title{
Analysis of genomic and non-genomic signalling of oestrogen receptor in PDX models of breast cancer treated with a combination of the PI3K inhibitor Alpelisib (BYL719) and fulvestrant
}

Muriel Le Romancer ( $\nabla$ muriel.leromancer@lyon.unicancer.fr )

INSERM https://orcid.org/0000-0002-8491-4015

Julien Jacquemetton

Centre Leon Berard

Loay Kassem

Cairo University

Coralie Poulard

INSERM

Ahmed Dahmani

Institut Curie

Ludmilla De PLATER

Institut Curie

Elodie Montaudon

Institut Curie

Laura Sourd

Institut Curie

Ludivine Morisset

institutCURIE

Rania El Botty

Institut Curie

Sophie Chateau-Joubert

Ecole Nationale Veterinaire d'Alfort

Sophie Vacher

Institut Curie

Ivan Bieche

Institut Curie

Isabelle Treilleux

Centre Leon Berard

Olivier Trédan

Centre Leon Berard 


\section{Elisabetta Marangoni}

Institut Curie

\section{Research}

Keywords: Breast cancer, oestrogen signalling, resistance, PI3K, PDX, biomarker

Posted Date: August 7th, 2020

DOI: https://doi.org/10.21203/rs.3.rs-54785/v1

License: (c) (1) This work is licensed under a Creative Commons Attribution 4.0 International License. Read Full License 


\section{Abstract}

Background Endocrine therapies targeting oestrogen signalling have significantly improved breast cancer (BC) patient survival, although $40 \%$ of ERa-positive BCs do not respond to those therapies. Aside from genomic signalling, oestrogen triggers non-genomic pathways by forming a complex containing methylERa/Src/PI3K, a hallmark of aggressiveness and resistance to tamoxifen. We aimed to confirm the prognostic value of this complex and investigated whether its targeting could improve tumour response in vivo.

Methods The interaction of $\mathrm{ERa} / \mathrm{Src}$ and $\mathrm{ERa} / \mathrm{PI} 3 \mathrm{~K}$ was studied by proximity ligation assay (PLA) in a cohort of $440 \mathrm{BC}$ patients. We then treated patient-derived BC xenografts (PDXs) with fulvestrant or the PI3K inhibitor alpelisib (BYL719) alone or in combination. We analysed their anti-proliferative effects on 6 $\mathrm{ERa}+$ and $3 \mathrm{ERa}-\mathrm{PDX}$ models. Genomic and non-genomic oestrogen signalling were assessed by measuring ERa/PI3K interaction by PLA or the expression of key oestrogen target genes by RT-QPCR, respectively.

Results We confirmed that $\mathrm{ERa} / \mathrm{Src}$ and especially $\mathrm{ERa} / \mathrm{PI} 3 \mathrm{~K}$ interaction were associated with a trend to poorer survival. In ERa + tumours, the combination of BYL719 and fulvestrant was more effective than fulvestrant alone in 3 models, irrespective of PI3K, PTEN status or ERa/PI3K targeting. Interestingly, in some ERa- models, fulvestrant alone impacted tumour growth and this was associated with a decrease in $\mathrm{ERa} / \mathrm{PI} 3 \mathrm{~K}$ interaction.

Conclusions Our results demonstrate that $\mathrm{ERa} / \mathrm{PI} 3 \mathrm{~K}$ may constitute a new prognostic marker, as well as a new target in BC. Indeed, resistance to fulvestrant was clearly associated with a lack of ERa/PI3K targeting in the cytoplasm.

\section{Background}

Breast cancer (BC) is the most common cancer among women worldwide [1]. More than $75 \%$ of breast tumours express the oestrogen receptor $a(E R a)$ in the nucleus and are commonly categorised as luminal BCs. ERa plays a major role in BC tumorigenesis as it regulates cell cycle, cell survival and angiogenesis [2]. Interfering with the ERa pathway using anti-oestrogens (selective estrogen receptor modulators such as tamoxifen or selective estrogen downregulators such as fulvestrant) or through oestrogen deprivation (e.g., aromatase inhibitors), increases the survival of ERa-positive BC patients. Despite the high level of sensitivity of luminal tumours to endocrine therapy, treatment efficacy is limited by intrinsic and acquired resistance [3, 4]. Indeed, $30-50 \%$ of patients relapse after adjuvant treatment and eventually die from metastases [5].

PIK3CA gene, encoding the p110a subunit of PI3K, is mutated in $40-50 \%$ of ERa + tumours, suggesting a dependency of ERa + breast cancer cells on this pathway [6, 7]. Given the role of PI3K in supporting proliferation, survival, and hormone receptor pathway activity, it is not surprising that activation of $\mathrm{PI} 3 \mathrm{~K} / \mathrm{AKT} / \mathrm{mTOR}$ pathway promotes disease progression and resistance to endocrine therapy [8]. PI3KCA 
mutated preclinical cancer models are sensitive to PI3K inhibitors, which appear to function synergistically with endocrine therapies [9]. This was recently confirmed in patients, as treatment with alpelisib (PI3K inhibitor) combined to fulvestrant prolonged survival of PIK3CA-mutated patients [10]. At the molecular level, ERa and PI3K pathways crosstalk at different levels [3]. At the genomic level, somatic activating mutations of the PIK3CA gene lead to abnormal PI3K/AKT/mTOR pathway activation [11]. In addition, PI3K inhibition increases ERa transcriptional activity via SGK1 and a feedback mechanism that attenuates the activity of PI3K inhibitors [12]. Beyond these genomic mechanisms of action, activation of PI3K pathway in BC can occur via a non-genomic signalling pathway involving cytoplasmic ERa [13,14]. Cytoplasmic ERa when complexed to Src and PI3K activates Akt, triggering proliferation and cell survival $[13,15-17]$. Our team reported that methylation of ERa on residue R260 by the arginine methyltransferase PRMT1 is a prerequisite for its association with Src and PI3K and the activation of Akt $[18,19]$. Subsequently, using the proximity ligation assay (PLA) methodology to detect in situ protein/protein interactions [20], we showed that this pathway, characterized by the formation of $\mathrm{ERa} / \mathrm{Src} / \mathrm{PI} 3 \mathrm{~K}$, is present in normal breast tissue and is hyperactivated in aggressive breast tumours [21]. Moreover, we unveiled that $\mathrm{ERa} / \mathrm{Src}$ and $\mathrm{ERa} / \mathrm{PI} 3 \mathrm{~K}$ interaction is associated with resistance to tamoxifen [22].

Taken together, these data introduced the concept that the non-genomic oestrogen pathway, in addition to the presence of activating PIK3CA mutations could affect the response to PI3K inhibitors associated with endocrine treatments.

In this study, we first evaluated $\mathrm{ERa} / \mathrm{Src}$ and $\mathrm{ERa} / \mathrm{PI} 3 \mathrm{~K}$ interaction in a large cohort of $\mathrm{BC}$ patients. We then treated different PDX models of PIK3CA mutated and WT breast cancer with the PI3K inhibitor BYL719 combined to fulvestrant and explored their effect on tumour growth as well on both genomic and non-genomic ERa pathways.

\section{Materials And Methods}

\section{Human breast cancer sample collection}

The tumours from 440 patients of the Centre Léon Bérard (CLB) with invasive non-metastatic breast cancer, whose clinical and biological data were available from the regularly updated institutional database, were analysed. Written informed consent was obtained from each patient. The study protocol was approved by the institutional ethics committee. Patient characteristics are presented in the Additional material, (Additional File 2, Table S1). In our study, tumours exhibiting less than $10 \%$ of ERa-positive cells were considered to be ERa-negative tumours.

\section{Patient-derived xenografts}


Before PDX establishment, all patients had previously given their verbal informed consent for experimental research on residual tumour tissue available after histopathological analyses. PDX establishment was performed after approval of the ethics committee of the Institut Curie. According to the French rules and the ethics committee of the Institut Curie, a written consent from patients to obtain residual tumour tissues is not required.

Nine breast cancer PDX models were used in this study. They were established from surgical specimens by grafting tumour fragments into the interscapular fat pad of nude mice as previously described [22-23]. Female Swiss nude mice, 10-week-old, were purchased from Charles River (Les Arbresles, France) and maintained under specific pathogen-free conditions. Their characteristics are described in the Additional material (Additional File 3, Table S2). Their care and housing were in accordance with institutional guidelines and the rules of the French Ethics Committee (project authorization no. 02163.02). Histological and IHC statuses (ERa, PR, and HER2) were determined for the PDXs and compared with that of the patient tumour samples, as described elsewhere [23].

When tumours reached a volume of 60 to $200 \mathrm{~mm}^{3}$, mice were randomly assigned to the control or treatment groups, each group consisting of seven or eight mice. Fulvestrant (Faslodex ${ }^{\circledR}$, AstraZeneca, Macclesfield, UK) was administered by intramuscular injection at a dose of $200 \mathrm{mg} / \mathrm{kg}$ once a week. BYL719 was purchased from Medchemexpress and was administered orally at $35 \mathrm{mg} / \mathrm{kg} 5$ times per week. Tumour growth was evaluated by measuring two perpendicular diameters of tumours with a caliper

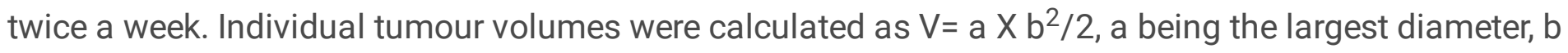
the smallest. Tumour growth inhibition (TGI) of treated tumours versus controls was calculated as the ratio of the mean tumour volume in the treated group to the mean tumour volume in the control group at the same time (end of the experiment). Statistical significance of TGI was calculated using the paired Student's $t$ test by comparing the tumour volumes in the treated and control groups. Percent change in tumour volume was calculated for each tumour using the following formula: [(Vf-V0)/V0]*100; where V0= Initial volume (at the beginning of treatment) and $\mathrm{Vf}=$ Final volume (at the end of treatment). Classification of tumour response in waterfall plots: tumour regression, stabilization and progression corresponded to a percent of volume change lower, equal or $>0$, respectively.

Tumour sampling was performed $24 \mathrm{hr}$ after the last experiment. No specific toxicity was reported in the experiments, neither diarrhoea, nor rash was observed and treated mice did not display any important weight loss throughout the experiment time-course. 


\section{Antibodies}

\begin{tabular}{|lllll|}
\hline Antibodies & Supplier & Origin & $\begin{array}{c}\text { Dilution } \\
\text { for PLA }\end{array}$ & Dilution for IHC \\
\hline PI3K p85 & Abcam & mouse & $1 / 30$ & \\
ab-22653 & & & & \\
c-Src (B12) & SCBT & mouse & $1 / 150$ & \\
sc-8056 & & & & \\
\hline ERa (HC20) & SCBT & rabbit & $1 / 75$ & \\
Sc-542 & & & & \\
\hline ERa (SP1) & Roche & rabbit & & \\
05278406001 & & & & $1 / 75$ \\
\hline p-AKT (Ser473) & CST & rabbit & & \\
4060 & & & & $1 / 100$ \\
\hline p-S6RP (Ser235/236) & CST & rabbit & \\
4857 & & & & \\
\hline PTEN & CST & rabbit & \\
9559 & & & & \\
\hline
\end{tabular}

\section{Proximity ligation assay in tissues}

This technology, first published in 2006 [20], enables the in situ visualization of protein-protein interactions and was supplied by Merck. Paraffin-fixed tumour tissues incorporated in TMA blocks were initially sectioned and incubated in a hydrogen peroxide solution, for $5 \mathrm{~min}$ at room temperature, to avoid peroxidase quenching. The antibody labelling steps were similar to those described above. For antibody detection, the probes were labelled with horseradish peroxidase after two washes in high purity water. A nuclear staining solution was added to the slides and incubated $2 \mathrm{~min}$ at room temperature. After 
washing the slides 10 min under running tap water, the samples were consecutively dehydrated in ethanol and xylene. Samples were mounted in non-aqueous mounting medium and visualized under a bright-field microscope. The protocol has already been optimized for ERa/Src and ERa/PI3K interactions [18,21].

\section{Image acquisition and analysis}

The hybridized fluorescent slides were viewed under a Leica DM6000B microscope. Images were acquired under identical conditions at X63 magnification. Images of three independent zones on each tumour were acquired under identical conditions at X40 magnification. At least, 500 cells were counted per tumour.

\section{Statistical analysis}

$\mathrm{ERa} / \mathrm{Src}$ and $\mathrm{ERa} / \mathrm{PI} 3 \mathrm{~K}$ interaction in invasive breast cancer samples (by bright field microscopy) was quantified as the mean number of dots (denoting interaction) per cell. For the sake of correlation and survival analyses, a cutoff for interaction was defined at the most discriminative difference in DFS and OS as calculated by Kaplan Meier estimates. Accordingly, ERa/Src interaction was defined as high if mean number of dots/cell $>10$ and low if $\leq 10$ dots/cell, while ERa/PI3K interaction was high if $>9$ dots/cell and low if $\leq 9$ dots/cell. Correlations between the 2 biomarkers ERa/Src and ERa/PI3K were studied. The Pearson's correlation coefficient was presented with asterisks highlighting identify its significance $(*: p<0.05 ; * *: p<0.01 ; * \star *: p<0.001)$. Associations between categorical variables were studied using Pearson's Chi square test. Overall survival (OS) defined as time from diagnosis to death or date of last follow-up and disease-free survival (DFS) defined as time from diagnosis to death or relapse or date of last follow-up (for censored patients) were studied.

Survival curves were estimated by Kaplan-Meier method and compared between groups with different interaction levels using the Log-Rank test.

\section{RT-QPCR analysis}

RNA extraction was performed as previously described [26,27]. Quantitative values were obtained from the number of the cycle ( $\mathrm{Ct}$ value) at which the increase in the fluorescent signal associated with exponential growth of PCR products was initially detected by the laser detector of the ABI Prism 7900 sequence detection system (Perkin-Elmer Applied Biosystems, Foster City, CA), using PE biosystems analysis software according to the manufacturer's manuals.

For gene normalization, we used the human TATA box-binding protein (TBP, GeBbank accession no. NM_003194). We used protocols for cDNA synthesis and PCR amplification described in detail elsewhere 
[28]. Results, expressed as $\mathrm{N}$-fold differences in target gene expression relative to the TBP gene and termed "Ntarget", were determined as Ntarget $=2^{\Delta C \text { tsample }}$, where the $\Delta C t$ value of the sample obtained by subtracting the average $\mathrm{Ct}$ value of target gene from the average $\mathrm{Ct}$ value of TBP gene.

\section{IHC experiments}

Xenografted tumours were fixed in $10 \%$ neutral buffered formalin, paraffin embedded, and haematoxylineosin-saffron (HES) stained. Outgrowths were analysed by immunohistochemistry (IHC) for expression of biomarkers. Immunostaining was performed on a Discovery XT Platform (Ventana Medical System, Tucson, AZ, part of Roche Diagnostics) with antigen retrieval using either EDTA buffer, pH 8.0 (CC1, Ventana Medical System) or citrate buffer 10 mM, pH 6.0, (CC2, Ventana Medical System). Primary antibodies were mostly monoclonal rabbit antibodies and paired slides immunostained with rabbit lgG were used as negative controls. Incubation and colour development involved anti rabbit multimer secondary antibody (horseradish peroxydase complex) with DAB (3,30-diaminobenzidine tetrahydrochloride) as substrate (ChromoMap Kit with Anti-rabbit OmniMap, Ventana Medical System). The IHC slides were scanned with Pannoramic SCAN II (3DHISTECH). Then we used HALO software (Indica labs) to quantify the expression levels of ERa, pAkt(S473) and pS6(S235/6).

\section{Results}

\section{Clinicopathological characteristics of the patient cohort}

Among the 440 patients, 433 had complete clinical data, 430 were assessable for ERa/Src interaction and 417 were assessable for ERa/PI3K interaction. Median age at diagnosis was 57.9 years (range: 30.4 to 87.4 years). Regarding the tumour stage, $41.8 \%$ of the patients had tumours beyond $20 \mathrm{~mm}$, and $57.5 \%$ displayed axillary LN metastasis. Only $18.9 \%$ of the patients had SBR grade I tumours, $47.8 \%$ had grade II tumours and $33.3 \%$ grade III tumours. ER was positive in $87.1 \%$, PR in $74.8 \%$ and HER2 was overexpressed in $7.2 \%$ of the cohort. Table S1 shows the clinico-pathological characteristics of the tested patient cohort (433 patients).

Representative micrographs of tumour cells with high (tumour\#2) and low levels of interaction (tumour\#1) of ERa/Src and ERa/PI3K are shown in fig. 1a. ERa/Src interaction was high (> 10 dots) in 174 cases $(40.5 \%)$, while 256 of cases $(59.5 \%)$ showed low levels of interaction ( $\leq 10$ dots). ERa/PI3K interaction was high ( $>9$ dots) in 156 cases $(37.4 \%)$, while 261 of cases $(62.6 \%)$ displayed low levels of interaction ( $\leq 9$ dots). Interestingly, we observed a positive association between ERa/Src and ERa/PI3K interactions $(p<0.001)$ (Table 1). We observed no correlation between high levels of interaction of either $\mathrm{ERa} / \mathrm{Src}$ (Table 2) or ERa/PI3K (Table 3) with any of the traditional prognostic parameters of breast cancer. 
High levels of ERa/PI3K interaction are associated with poorer breast cancer patient outcome

No significant impact on either OS (HR=1.24; 95\% Cl: $0.79-1.94 ; \mathrm{p}=0.343)$ or DFS (HR=1.21; $95 \% \mathrm{Cl}$ : 0.83$1.75 ; p=0.325$ ) was noted for patients displaying high or low levels of $E R a / S r c$ interactions (Fig. 1b.). Conversely, ERa/PI3K interaction predicted a trend towards poorer OS and DFS (Fig. 1c.), with an 8-year OS rate of $79.2 \%$ in patients with low levels versus $72.4 \%$ in patients with high levels of ERa/PI3K interaction ( $\mathrm{HR}=1.55 ; 95 \% \mathrm{Cl}$ : $0.99-2.44 ; \mathrm{p}=0.055)$, and an 8-year DFS rate of $79.2 \%$ in patients with low levels versus $72.4 \%$ in patients with high levels of $\mathrm{ERa} / \mathrm{PI} 3 \mathrm{~K}$ interaction $(\mathrm{HR}=1.35 ; 95 \% \mathrm{Cl}: 0.93-1.97 ; \mathrm{p}=$ 0.116).

\section{Targeting oestrogen genomic and non-genomic signalling in ERa-positive PDX models}

Based on the present data and our previous results [21,22], we hypothesized that the oestrogen nongenomic pathway could represent a therapeutic target in BC and particularly in endocrine resistant ERa+ BCs. To test our hypothesis, we targeted non-genomic signalling using a combination of endocrine therapy (fulvestrant), known to degrade ERa, and a PI3K inhibitor, known to disrupt the complex containing ERa/PI3K and its downstream signalling [21], As our previous results were obtained with LY294002, not used in clinic, we studied the effect of three other PI3K inhibitors on MCF-7 cells and found that BYL719 was the most effective at decreasing the interaction of ERa with PI3K (Additional File 4, Figure S1). This inhibitor was thus selected for further in vivo experiments.

The treatment efficacy was tested in 6 PDX models of ERa+ breast cancers. The characteristics of the different PDXs are summarized in the additional File 3 Table S2. Five of these models were established from primary breast tumours and one from a bone metastasis. Three models (HBCx-86, HBCx-91 and BC1111) are PIK3CA mutated: p.E545Kand BC1111: p.H1047R).

First, we evaluated the efficacy of fulvestrant alone, BYL719 alone, or BYL719 + fulvestrant in a PIK3CA WT hormone-sensitive PDX, HBCX-34 (Fig. 2a.). In this PDX model, treatment by fulvestrant for 3 months resulted in tumour regression in 5/8 xenografts, stable disease in 1 xenograft and complete response in 1 xenograft. Tumour response increased in the combination group ( $p=0.01$, Mann Whitney test) with $6 / 10$ xenografts displaying complete responses, 3 tumour regression and 1 stable disease (Fig. 2b.).

In this PDX model, the ERa/PI3K interaction was significantly reduced by fulvestrant alone or combined with BYL719, but BYL719 alone had no effect (Fig. 2c.). The analysis of some oestrogen-regulated genes (ERG) showed a trend in the up-regulation of PGR, GREB1 and TFF1 gene expression in BYL719-treated xenografts and a significant decrease in the expression of the same genes in xenografts treated with fulvestrant or the combination (Fig. 2d.). ESR1 expression remained unchanged. IHC staining validated that ERa expression decreased upon fulvestrant treatment and that BYL719 inhibited downstream PI3K signalling only combined with fulvestrant, as evidenced by P-S6 riboprotein (S235/6) expression (Fig. 2e, 
additional File S6 Figure S3). This tumour does not express P-Akt (S473), so we couldn't confirm BYL719 efficacy on PI3K signaling.

Two other models responded partially to BYL719 and fulvestrant alone, and the combination increased this anti-tumoral effect. In the PDX HBCX-3, the combination of BYL719 and fulvestrant did not inhibit tumour growth (Fig. 3a.), although this was significantly decreased compared to the control (TGI of $62 \%$ and $65 \%$, respectively). The PIK3CA-mutated $\mathrm{HBCx}-86$ model responded to the combination by exhibiting remarkable tumour regression (Fig. 3b.). For these models, ERa/PI3K interaction was efficiently disrupted with fulvestrant but not with BYL719 alone (Fig. 3c, d). Conversely, ERG remained unaffected irrespective of the treatment (Fig. 3e, f). IHC staining revealed that for both models, fulvestrant treatment decreased ERa expression (Fig. 3g, h, additional File 7, Fig S4, additional File 8, Fig S5). However, concerning BYL719 efficacy, it has no effect in the HBCx-3 model (Fig. 3g, additional File 7, Fig S4), whereas it significantly decreased P-S6 riboprotein (S235/6) staining (Fig. 3h, additional) in HBCx-86 model (Fig 3h, additional File 8, Fig S5). We couldn't confirm this result with Akt staining that was too low.

These results suggest that the effects of fulvestrant on tumour growth are potentiated following PI3K inhibition in a context of oestrogen non-genomic signalling.

Next, we studied 2 models of PDX resistant to fulvestrant. The HBCx-22 TamR model did not respond significantly to BYL719 alone or in combination with fulvestrant (Fig. 4a.). The BC1111 model, was resistant to BYL719, however the combination strongly inhibited tumour growth (TGI 79\%, P < 0.0001) (Fig. 4b.). Interestingly, in the 2 models, ERa/PI3K interaction was not significantly decreased upon treatment, fulvestrant having an opposite effect in the HBCx-22 Tam R model by significantly increasing this interaction (Fig. 4c, d), corroborating our previous findings [22]. The expression of ERG diminished following fulvestrant or combination treatment administration, whereas it increased with BYL719 (Fig. 4e, f). IHC staining of the HBCX-22 TamR model revealed that fulvestrant strongly inhibited ERa nuclear expression, while BYL719 had no effect on PI3K signalling (Fig. 4g, additional File 9 Fig S6).

With regards to the BC1111 model, fulvestrant triggered a decrease in ERa expression, while BYL719 efficiently inhibited the PI3K pathway (Fig. 4h, additional File 10 Fig S7).

We then investigated another ERa-positive PDX model engrafted from a patient expressing a low level of ERa and harbouring a PI3KCA mutation, $\mathrm{HBCx}-91$. This model was resistant to fulvestrant alone but responded to BYL719 alone or in combination with fulvestrant, by inducing a stable low-grade disease (Fig. 5a.). We observed a significant increase in ERa/PI3K interaction upon fulvestrant treatment, whereas BYL719 alone or in combination had no effect (Fig. 5b.). The expression of ERG was not significantly affected by the different treatments (Fig. 5c.). The IHC staining confirmed that ERa was faintly expressed in the nucleus of tumoral cells (Fig. 5d.). Fulvestrant induced a significant decrease in ERa expression and BYL719 efficiently targeted the PI3K pathway (Fig. 5d, additional File 11, Fig S8). 


\section{Targeting oestrogen non-genomic signalling in ERa-negative PDX models}

As the oestrogen non-genomic complex is also activated in ERa-negative breast tumours [21] and the PI3K pathway is active in TNBC, we tested the combination of BYL719 + fulvestrant in 3 ERa-negative PDX models. In the HBCX-17 model (WT for PIK3CA), only the combination of BYL719 + fulvestrant inhibited tumour growth with a TGI of $64 \%(p=0.03$, Mann-Whitney t-test), although no tumour regression was observed (Fig. 6a.). Interestingly, fulvestrant and BYL719 alone significantly decreased ERa/PI3K formation, whereas the combination had no additive effect (Fig. 6b.). IHC analysis revealed a similar decrease in P-S6 riboprotein (S235/236) expression in tumours treated with BYL719 alone or combined with fulvestrant, altought it was less clear for p-Akt (Fig. 6c, additional File 11, Fig S9).

Next, we evaluated the impact of combining treatments in the HBCx-66 model. Fulvestrant had a modest effect on tumour growth, while administration of BYL719 alone or in combination led to a strong decrease in tumour volume (Fig. 6d.). BYL719 and fulvestrant significantly decreased ERa/PI3K interaction whereas the combination had no significant effect (Fig. 6e.). Similarly to the previous ERamodel, BYL719 showed a non-significant decrease in p-AKT (S473) and P-S6 riboprotein (S235/236) staining (Fig. 6f, aditionnal File 12, Fig S10).

In the HBCX-90 PDX (PI3KCA mutated) treatment with fulvestrant had no effect on tumour growth, whereas BYL719 or the combination significantly decreased tumour volume. Interestingly, in this model resistant to fulvestrant, the anti-oestrogen had no effect on ERa/PI3K interactions (Fig. 6h.). Conversely, BYL719 significantly inhibited the downstream PI3K pathway, but did not affect ERa/PI3K interaction (Fig. 6i, additional File 13, Fig S11).

In conclusion, in ERa-negative tumors, fulvestrant effect on tumour growth is linked to its ability to disrupt ERa interaction with PI3K.

\section{Discussion}

Based on our results and other existing literature, we postulated that the actors of oestrogen non-genomic signalling could constitute both new prognostic markers and new therapeutic targets. In this study, we sought to validate the activation of this pathway in aggressive breast cancers in a new cohort of breast tumour specimen. ERa/Src/PI3K being a hallmark of the non-genomic signalling, we studied ERa/Src and $\mathrm{ERa} / \mathrm{PI} 3 \mathrm{~K}$ by in situ PLA in a cohort of 440 invasive breast tumours. Interestingly, we found that their high level of expression was correlated with a decrease in patient survival, ERa/PI3K being associated with the most pronounced effects. These data corroborate those obtained in a first cohort of 175 BCs [21] and justify to investigate the targeting of $\mathrm{ERa} / \mathrm{PI} 3 \mathrm{~K}$ in in vivo models of $\mathrm{BCs}$.

As a proof-of-concept, we decided to target ERa/PI3K interactions using an anti-oestrogen (fulvestrant), or a PI3K inhibitor alone (BYL719) or in combination in 6 models of ERa + and $3 \mathrm{ERa}-\mathrm{BC}$ PDXs. For the ERa- 
positive models, we evaluated their effect on tumour growth as well as on oestrogen non-genomic signalling (by studying ERa/PI3K interaction) and on genomic signalling (by studying the expression of ERa target genes). For the ERa-negative models, we assessed the efficacy of treatments on tumour growth and on ERa/PI3K interactions. We decided to use a PI3K inhibitor acting predominantly against $\mathrm{PI} 3 \mathrm{Ka}$, as it has been largely shown by our team and others that treating BC cells with PI3K inhibitors disrupts ERa/PI3K interactions in ERa-positive cell lines [13, 15, 21]. We confirmed this result in the present study using BYL719 and showed that it was able to disrupt ERa/PI3K interactions in MCF-7 cells. However, our present work reveals that BYL719 had no significant effect in vivo on ERa/PI3K interactions in ERa + PDX models tested. For 3 of them, this could be explained because the inhibitor had no clear effect on PI3K signalling and for two PDX models resistant to fulvestrant, ERa/PI3K could also not be disrupted by fulvestrant. These results suggest that it would be better to find novel molecules able to destabilize this interaction. As a proof-of-concept, Aurrichio's team recently showed that a peptide targeting the site of interaction between $\mathrm{ERa} / \mathrm{Src}$ was able to disrupt $\mathrm{ERa} / \mathrm{Src} / \mathrm{PI} 3 \mathrm{~K}$ complex formation, as well as cell proliferation in vitro and in vivo [29]. At the opposite, in 2 ERa-negative models, BYL719 was able to decrease ERa/PI3K interaction, supporting the idea that PI3K activity is important for its binding to cytoplasmic ERa. However, this effect does not seem to be associated with response to tumour growth as BYL719 has no effect on ERa/PI3K interaction in HBCx-90 model although it has an impact on tumour growth.

In summary, of the 6 PDX of ERa + BCs tested, 4 responded to the combination of BYL719 + fulvestrant, 3 of which were PIK3CA mutated. Activation of the non-genomic ERa pathway decreased in treated tumours of 3 PDXs, due largely to fulvestrant and was not always associated with the in vivo response (HBCX-3). The combination of BYL719 and fulvestrant was more efficient than fulvestrant alone in 3 models, however this effect was not associated with decreased levels of ERa/PI3K complex in xenografts treated with the combination compared to fulvestrant-treated xenografts. Similarly, PI3K dependent regulation of ERa transcription was observed only in 3 PDXs and was not correlated to PIK3CA mutations nor to response to the PI3K inhibitor. However, in order to obtain a strong tumour response to combined therapy, it is necessary to simultaneously inhibit genomic and non-genomic signalling. Indeed, complete responses were obtained in $\mathrm{HBCx}-34$ xenografts, where both pathways were inhibited. However, when only one pathway was inhibited, the response was partial, as evidenced for $\mathrm{HBC} 33$ and $\mathrm{HBC} \times 86$, in which only the non-genomic pathway was inhibited by fulvestrant, whereas for HBCx-22 TamR and BC1111 models, only the genomic pathway was inhibited. For the HBCx-91 model, the response was partial and both oestrogen signalling pathways remained unresponsive to fulvestrant. Interestingly, in the 3 models resistant to fulvestrant, ERa/PI3K was not disrupted. Inversely, in 2 cases their interaction increased, although ERa was efficiently degraded in the nucleus and ERG expression was downregulated. This is in accordance with recent results from our lab showing that ERa/PI3K interaction increases upon resistance to endocrine therapy [22]. Of note in the HBCx-22, where the increase of ERa/PI3K interaction upon fulvestrant is very strong, PI3K pathway is activated, suggesting that this interaction may activate PI3K activity and the downstream pathway, increasing resistance to treatment inducing tumor growth. 
Unlike previous findings [12], we observed no increase in ERa expression at the mRNA or the protein levels in the 6 ERa-positive models treated with BYL719, likely due to the different models investigated (in cellulo vs in vivo)

Concerning ERa-negative models, in $\mathrm{HBCx}-17$ and $\mathrm{HBCx}-66$ tumours, fulvestrant had a modest effect on growth inhibition. Interestingly, in these models, fulvestrant alone was able to decrease PI3K pathway probably by disrupting $\mathrm{ERa} / \mathrm{PI} 3 \mathrm{~K}$ interactions which might affect $\mathrm{PI} 3 \mathrm{~K}$ activity and then downstream signalling. Conversely, in the HBCx-90 model, where fulvestrant had no effect on tumour growth, neither $\mathrm{ERa} / \mathrm{PI} 3 \mathrm{~K}$ interaction nor the downstream pathway were inhibited.

Altogether, our results confirm that $\mathrm{ERa} / \mathrm{PI} 3 \mathrm{~K}$ interaction could be evaluated before associating endocrine therapy with PI3K inhibitors in BC. Moreover, targeting this interaction may improve the response to endocrine therapy in ERa-positive tumours and patient survival in ERa-negative BCs.

\section{Conclusions}

In summary, the present study identifies ERa/PI3K interaction, a hallmark of oestrogen non-genomic signalling, as a new biomarker associated with a decrease in BC patient survival. In addition, targeting this interaction may circumvent resistance to endocrine therapies in ERa-positive tumours and could contribute to decreasing tumour growth in ERa-negative tumours.

\section{Declarations}

\section{Ethical Approval and Consent to participate}

Before PDX establishment, all patients had previously given their verbal informed consent for experimental research on residual tumour tissue available after histopathological analyses.

PDX establishment was performed after approval of the ethics committee of the Institut Curie.

Written informed consent was obtained from each patient. The study protocol was approved by the institutional ethics committee.

\section{Consent for publication}

All authors gave consent for the publication of the manuscript in Cancer and Metabolism.

\section{Availability of supporting data}

All data in our study are availability upon request.

\section{Competing interests}


The authors declare that they have no conflict of interest.

\section{Authors' contributions:}

MLR and EM designed the experiments and wrote the manuscript. JJ and CP performed the experiments and the analyses. LK performed the statistical analyses. OT and IT participated in the discussion of the results and the writing of the manuscript.

AD, LDP, EM, LS, LM established the PDX models and performed the in vivo experiments. REB, SV and IB performed RNA extractions and RT-PCR experiments. SCJ embedded tumour tissues in paraffin blocks and generated tissue slides for IHC staining. All authors reviewed and approved the final draft of the manuscript.

\section{Funding:}

We thank Fondation Arc Cancer, Fondation de France, INCA and DGOS for the financial support of the project. Fondation Arc Cancer and DGOS for JJ's wages.

\section{Acknowledgements}

We would like to thank B. Manship for proofreading the manuscript. We also thank Amelie Colombe and Laetitia Odeyer for technical help. XXXX thank platform

\section{-Authors' information}

-Centre de Recherche en Cancérologie de Lyon, Lyon, France : Julien Jacquemetton, Coralie Poulard, Muriel Le Romancer

-Clinical Oncology Department, Faculty of Medicine, Cairo University, Cairo, Egypt: Loay Kassem

-Translational Research Department, Institut Curie, PSL university, 75005 Paris, France: Elisabetta Marangoni, Ahmed Dahmani, Ludmilla De Plater, Elodie Montaudon, Laura Sourd, Ludivine Morisset, Rania El Botty

-École Nationale Vétérinaire d'Alfort, BioPôle Alfort, 94704 Maisons-Alfort Cedex : Sophie Chateau-Joubert -Genetics Department, Institut Curie, Paris, France: Yvan Bièche, Sophie Vacher

-Centre Léon Bérard, Pathology Department, F-69000 Lyon, France : Isabelle Treilleux

-Centre Léon Bérard, Medical Oncology Department, F-69000 Lyon, France : Olivier Trédan

\section{References}


1. Ferlay J, Soerjomataram I, Dikshit R, Eser S, Mathers C, Rebelo M, Parkin DM, Forman D, Bray F. Cancer incidence and mortality worldwide: sources, methods and major patterns in GLOBOCAN 2012. Int J Cancer. 2015;136: E359-E386. 10.1002/ijc.29210 [doi].

2. Santen RJ, Boyd NF, Chlebowski RT, Cummings S, Cuzick J, Dowsett M, Easton D, Forbes JF, Key T, Hankinson SE, Howell A, Ingle J. Critical assessment of new risk factors for breast cancer: considerations for development of an improved risk prediction model. Endocr Relat Cancer. 2007; 14: 169-187. 14/2/169 [pii];10.1677/ERC-06-0045 [doi].

3. Musgrove EA, Sutherland RL. Biological determinants of endocrine resistance in breast cancer. Nat Rev Cancer. 2009; 9: 631-643. nrc2713 [pii];10.1038/nrc2713 [doi].

4. Ring A, Dowsett M. Mechanisms of tamoxifen resistance. Endocr Relat Cancer. 2004; 11: 643-658. 11/4/643 [pii];10.1677/erc.1.00776 [doi].

5. Zhang XH, Giuliano M, Trivedi MV, Schiff R, Osborne CK. Metastasis dormancy in estrogen receptorpositive breast cancer. Clin Cancer Res. 2013; 19: 6389-6397. 19/23/6389 [pii];10.1158/10780432.CCR-13-0838 [doi].

6. Isakoff SJ, Engelman JA, Irie HY, Luo J, Brachmann SM, Pearline RV, Cantley LC, Brugge JS. Breast cancer-associated PIK3CA mutations are oncogenic in mammary epithelial cells. Cancer Res. 2005; Dec 1;65(23):10992-1000.

7. Samuels Y, Velculescu VE. Oncogenic mutations of PIK3CA in human cancers. Cell Cycle. 2004 ; Oct;3(10):1221-4.

8. Miller TW, Hennessy BT, González-Angulo AM, Fox EM, Mills GB, Chen H et al. Hyperactivation of phosphatidylinositol-3 kinase promotes escape from hormone dependence in estrogen receptorpositive human breast cancer. J Clin Invest. Jul. 2010; 120(7):2406-13. doi: 10.1172/JCl41680.

9. Miller TW, Balko JM, Fox EM, Ghazoui Z, Dunbier A, Anderson H, Dowsett M, Jiang A, Smith RA, Maira SM, Manning HC, González-Angulo AM, Mills GB, Higham C, Chanthaphaychith S, Kuba MG, Miller WR, Shyr Y, Arteaga CL. ERa-dependent E2F transcription can mediate resistance to estrogen deprivation in human breast cancer. Cancer Discov. 2011 ; Sep;1(4):338-51. doi: 10.1158/21598290.CD-11-0101.

10. André F, Ciruelos E, Rubovszky G, Campone M, Loibl S, Rugo HS, Iwata H, Conte P, Mayer IA, Kaufman B, Yamashita T, Lu YS, Inoue K, Takahashi M, Pápai Z, Longin AS, Mills D, Wilke C, Hirawat S, Juric D; SOLAR-1 Study Group. Alpelisib for PIK3CA-Mutated, Hormone Receptor-Positive Advanced Breast Cancer. N Engl J Med. 2019; May 16;380(20):1929-1940. doi: 10.1056/NEJMoa1813904.

11. Sarbassov DD, Guertin DA, Ali SM, Sabatini DM. Phosphorylation and regulation of Akt/PKB by the rictor-mTOR complex. Science. 2005; Feb 18;307(5712):1098-101

12. Bosch A, Li Z, Bergamaschi A, Ellis H, Toska E, Prat A, Tao JJ, Spratt DE, Viola-Villegas NT, Castel P, Minuesa G, Morse N, Rodón J, Ibrahim Y, Cortes J, Perez-Garcia J, Galvan P, Grueso J, Guzman M, Katzenellenbogen JA, Kharas M, Lewis JS, Dickler M, Serra V, Rosen N, Chandarlapaty S, Scaltriti M, Baselga J. PI3K inhibition results in enhanced estrogen receptor function and dependence in 
hormone receptor-positive breast cancer. Sci Transl Med . 2015 ; Apr 15;7(283):283ra51. doi: 10.1126/scitransImed.aaa4442

13. Castoria G, Migliaccio A, Bilancio A, Di DM, de FA, Lombardi M, Fiorentino R, Varricchio L, Barone MV, Auricchio F. PI3-kinase in concert with Src promotes the S phase entry of oestradiol-stimulated MCF7 cells. EMBO J. 2001; 20: 6050-6059.10.1093/emboj/20.21.6050 [doi].

14. Simoncini T, Hafezi-Moghadam A, Brazil DP, Ley K, Chin WW, Liao JK. Interaction of oestrogen receptor with the regulatory subunit of phosphatidylinositol-3-OH kinase. Nature. 2000; 407: 538-541. $10.1038 / 35035131$ [doi].

15. Cabodi S, Moro L, Baj G, Smeriglio M, Di SP, Gippone S, Surico N, Silengo L, Turco E, Tarone G, Defilippi P. p130Cas interacts with estrogen receptor alpha and modulates non-genomic estrogen signaling in breast cancer cells. J Cell Sci. 2004; 117: 1603-1611. 10.1242/jcs.01025 [doi];117/8/1603 [pii].

16. Le Romancer M., Poulard C, Cohen P, Sentis S, Renoir JM, and Corbo L. Cracking the Estrogen Receptor's Posttranslational Code in Breast Tumors. Endocr Rev. 2011; Oct;32(5): 597-622. doi: 10.1210/er.2010-0016.

17. Song RX, Zhang Z, Santen RJ. Estrogen rapid action via protein complex formation involving ERalpha and Src. Trends Endocrinol Metab. 2005; 16: 347-353. S1043-2760(05)00184-0 [pii];10.1016/j.tem.2005.06.010 [doi].

18. Le Romancer M., Treilleux I, Leconte N, Robin-Lespinasse Y, Sentis S, Bouchekioua-Bouzaghou K, Goddard S, Gobert-Gosse S, Corbo L. Regulation of estrogen rapid signaling through arginine methylation by PRMT1. Mol Cell. 2008; 31: 212-221. S1097-2765(08)00433-4 [pii];10.1016/j.molcel.2008.05.025 [doi].

19. Le Romancer M., Treilleux I, Bouchekioua-Bouzaghou K, Sentis S, Corbo L. Methylation, a key step for nongenomic estrogen signaling in breast tumors. Steroids. 2010; 75: 560-564. S0039128X(10)00016-4 [pii];10.1016/j.steroids.2010.01.013 [doi].

20. Soderberg O, Gullberg M, Jarvius M, Ridderstrale K, Leuchowius KJ, Jarvius J, Wester K, Hydbring P, Bahram F, Larsson LG, Landegren U. Direct observation of individual endogenous protein complexes in situ by proximity ligation. Nat Methods. 2006; 3: 995-1000. nmeth947 [pii]; 10.1038/nmeth947 [doi].

21. Poulard C., Treilleux I, Lavergne E, Bouchekioua-Bouzaghou K, Goddard-Leon S, Chabaud S, Tredan O, Corbo L, Le Romancer M. Activation of rapid oestrogen signalling in aggressive human breast cancers. EMBO Mol Med. 2012; 4: 1200-1213. 10.1002/emmm.201201615 [doi].

22. Poulard C, Jacquemetton J, Trédan O, Cohen P, Treilleux I, Marangoni E and Le Romancer M. Oestrogen non-genomic signalling is activated in tamoxifen-resistant breast cancer. IJMS. 2019; PMID 31195751. 
23. Cottu P, Marangoni E, Assayag F, de CP, Vincent-Salomon A, Guyader C, de PL, Elbaz C, Karboul N, Fontaine JJ, Chateau-Joubert S, Boudou-Rouquette P, Alran S, Dangles-Marie V, Gentien D, Poupon MF, Decaudin D. Modeling of response to endocrine therapy in a panel of human luminal breast cancer xenografts. Breast Cancer Res Treat. 2012; 133: 595-606. 10.1007/s10549-011-1815-5 [doi].

24. Marangoni E, Vincent-Salomon A, Auger N, Degeorges A, Assayag F, de CP, de PL, Guyader C, De PG, Judde JG, Rebucci M, Tran-Perennou C, Sastre-Garau X, Sigal-Zafrani B, Delattre O, Dieras V, Poupon MF. A new model of patient tumor-derived breast cancer xenografts for preclinical assays. Clin Cancer Res. 2007; 13: 3989-3998. 13/13/3989 [pii];10.1158/1078-0432.CCR-07-0078 [doi].

25. Romanelli A, Clark A, Assayag F, Chateau-Joubert S, Poupon MF, Servely JL, Fontaine JJ, Liu X, Spooner E, Goodstal S, de Cremoux P, Bièche I, Decaudin D, Marangoni E. Inhibiting aurora kinases reduces tumor growth and suppresses tumor recurrence after chemotherapy in patient-derived triplenegative breast cancer xenografts. Mol Cancer Ther. 2012 ; Dec;11(12):2693-703. doi: 10.1158/1535-7163.MCT-12-0441-T

26. Bièche I, Parfait B, Laurendeau I, Girault I, Vidaud M, Lidereau R. Oncogene. Quantification of estrogen receptor alpha and beta in sporadic breast cancer. 2001: Dec 6;20(56):8109-15.

27. Marangoni E, Laurent C, Coussy F, El-Botty R, Château-Joubert S, Servely JL, de Plater L, Assayag F, Dahmani A, Montaudon E, Nemati F, Fleury J, Vacher S, Gentien D, Rapinat A, Foidart P, Sounni NE, Noel A, Vincent-Salomon A, Lae M, Decaudin D, Roman-Roman S, Bièche I, Piccart M, Reyal F. Capecitabine Efficacy Is Correlated with TYMP and RB1 Expression in PDX Established from TripleNegative Breast Cancers. Clin Cancer Res. 2018 ; Jun 1;24(11):2605-2615. doi: 10.1158/10780432.CCR-17-3490.

28. Tozlu S, Girault I, Vacher S, Vendrell J, Andrieu C, Spyratos F, Cohen P, Lidereau R, Bieche I. Identification of novel genes that co-cluster with estrogen receptor alpha in breast tumor biopsy specimens, using a large-scale real-time reverse transcription-PCR approach.Endocr Relat Cancer. 2006 ;Dec;13(4):1109-20.

29. Varricchio L, Migliaccio A, Castoria G, Yamaguchi H, de FA, Di DM, Giovannelli P, Farrar W, Appella E, Auricchio F. Inhibition of estradiol receptor/Src association and Cell Growth by an estradiol receptor alpha tyrosine-phosphorylated peptide. Mol Cancer Res. 2007; 5: 1213-1221. 5/11/1213 [pii];10.1158/1541-7786.MCR-07-0150 [doi].

\section{Tables}

Table 1: Correlation between ER $\alpha / \operatorname{Src}$ and $\mathrm{ER} \alpha / \mathrm{PI}$ K interactions 


\begin{tabular}{|l|l|lc|ll|l|}
\hline Variable & \multicolumn{2}{|l|}{ ER $\alpha /$ PI3K $\leq 9$} & \multicolumn{2}{|l|}{ ER $\alpha / P I 3 K>9$} & P \\
& & No. & $(\%)$ & No. & $(\%)$ & \\
& 261 & $(62.6)$ & 156 & $(37.4)$ & \\
\hline ER $\alpha /$ Src & -Low ( $\leq 10)$ & 181 & $(69.6)$ & 68 & $(44.2)$ & $<0.001$ \\
& -High (> 10) & 79 & $(30.4)$ & 86 & $(55.8)$ & \\
& & & & & & \\
\hline
\end{tabular}

Table 2. Distribution of clinical parameters according to $\mathrm{ER} \alpha / \mathrm{Src}$ expression

\begin{tabular}{|c|c|c|c|c|c|c|}
\hline \multirow[t]{3}{*}{ Variable } & & \multirow{2}{*}{\multicolumn{2}{|c|}{$\mathrm{ER} \alpha / \mathrm{SRC} \leq 10$}} & \multirow{2}{*}{\multicolumn{2}{|c|}{ ER $\alpha /$ SRC $>10$}} & \multirow[t]{3}{*}{$\mathrm{P}^{*}$} \\
\hline & & & & & & \\
\hline & & 256 & (59.5) & 174 & $(40.5)$ & \\
\hline \multirow[t]{2}{*}{ Age groups } & $-\leq 50 y$ & 76 & $(29.7)$ & 35 & $(20.1)$ & \multirow[t]{2}{*}{0.026} \\
\hline & $->50 y$ & 180 & (70.3) & 139 & (79.9) & \\
\hline \multirow[t]{2}{*}{ T. size } & $-\leq 2 \mathrm{~cm}$ & 152 & (59.4) & 97 & (55.7) & \multirow[t]{2}{*}{0.455} \\
\hline & $->2 \mathrm{~cm}$ & 104 & $(40.6)$ & 77 & (44.3) & \\
\hline \multirow[t]{2}{*}{ LN invasion } & $-N o$ & 108 & $(42.2)$ & 74 & $(42.5)$ & \multirow[t]{2}{*}{0.944} \\
\hline & -Yes & 148 & (57.8) & 100 & $(57.5)$ & \\
\hline \multirow[t]{3}{*}{ SBR grade } & $-G r 1$ & 44 & (17.2) & 37 & (21.3) & \multirow[t]{3}{*}{0.394} \\
\hline & $-G r 2$ & 129 & $(50.4)$ & 77 & (44.3) & \\
\hline & $-G r 3$ & 83 & (32.4) & 60 & $(34.5)$ & \\
\hline \multirow[t]{2}{*}{$\mathrm{ER} \alpha$ status } & -Negative & 34 & (13.3) & 21 & (12.1) & \multirow[t]{2}{*}{0.712} \\
\hline & -Positive & 222 & (86.7) & 153 & (87.9) & \\
\hline \multirow[t]{2}{*}{ PR status } & -Negative & 61 & $(23.8)$ & 47 & $(27.0)$ & \multirow[t]{2}{*}{0.455} \\
\hline & -Positive & 195 & $(76.2)$ & 127 & (73.0) & \\
\hline \multirow[t]{2}{*}{ HER2 status } & -Negative & 238 & (83.7) & 157 & (91.3) & \multirow[t]{2}{*}{0.345} \\
\hline & -Positive & 16 & $(6.3)$ & 15 & $(8.7)$ & \\
\hline \multirow[t]{4}{*}{ Breast Ca. Subtype } & -Luminal A & 146 & $(57.0)$ & 95 & $(54.6)$ & \multirow[t]{4}{*}{0.876} \\
\hline & -Luminal B & 76 & (29.7) & 58 & (33.3) & \\
\hline & -HER2 rich & 7 & $(2.7)$ & 4 & $(2.3)$ & \\
\hline & $-T N B C$ & 27 & $(10.5)$ & 17 & $(9.8)$ & \\
\hline \multirow[t]{2}{*}{ Type of adjuvant hormonal } & -Tamoxifen & 93 & $(42.3)$ & 78 & $(52.3)$ & \multirow[t]{2}{*}{0.057} \\
\hline & $-A I$ & 127 & $(57.7)$ & 71 & $(47.7)$ & \\
\hline
\end{tabular}

Table 3. Distribution of clinical parameters according to ER $\alpha /$ PI3K expression

\section{Figures}




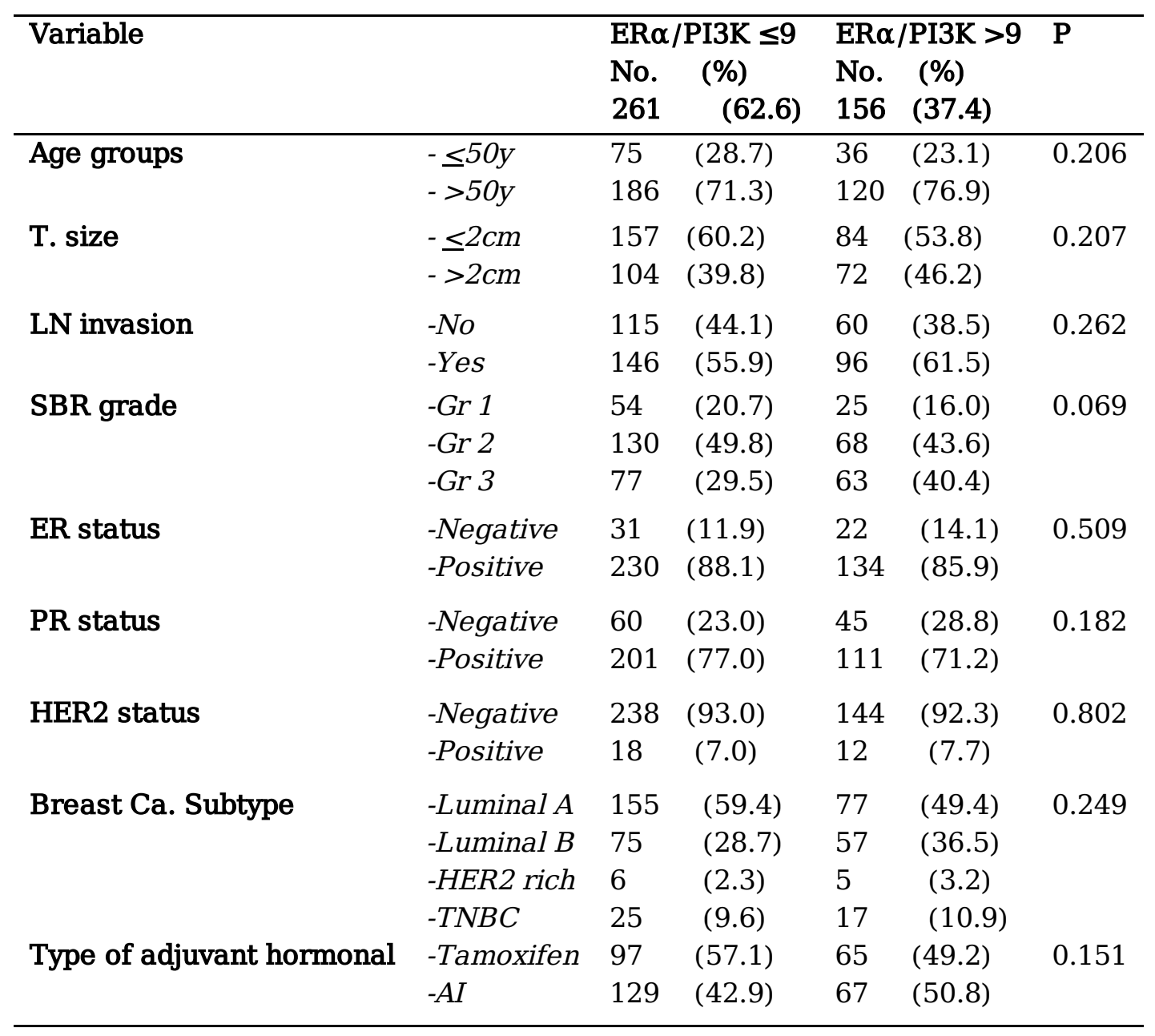




\section{Tumour \#2}
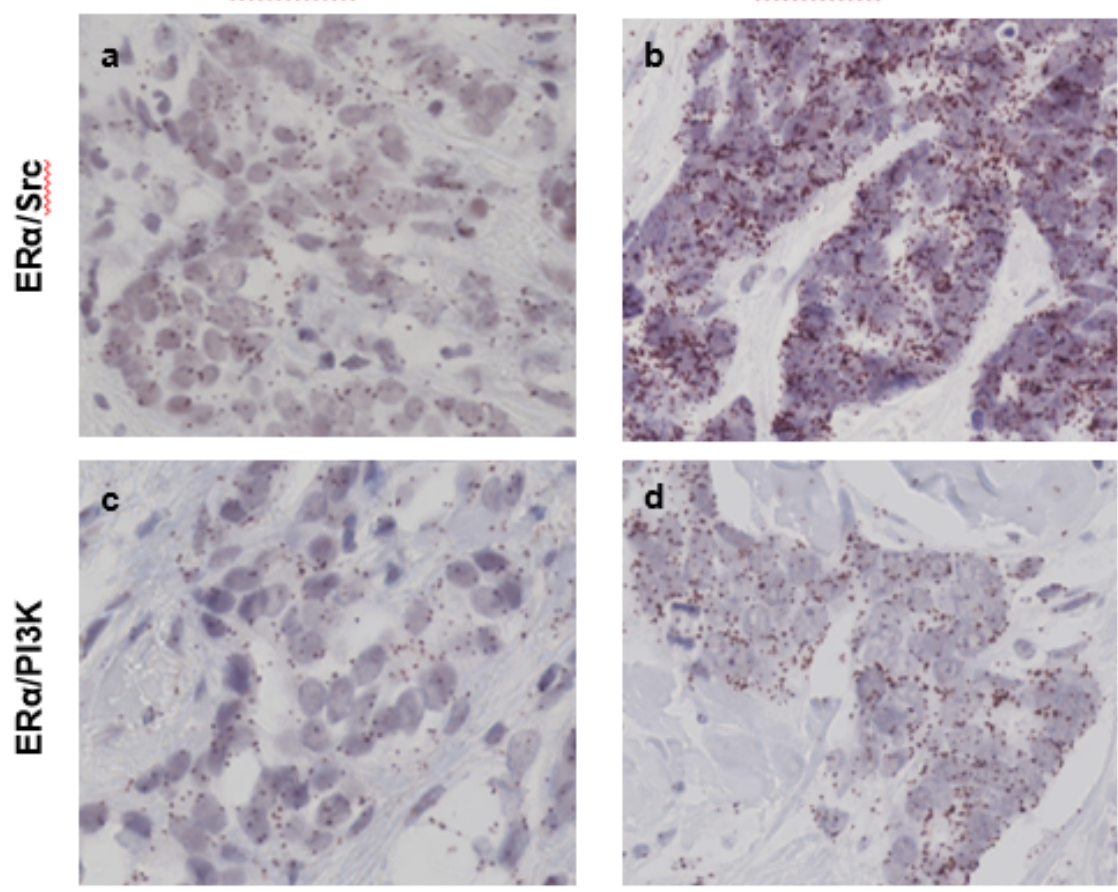

b
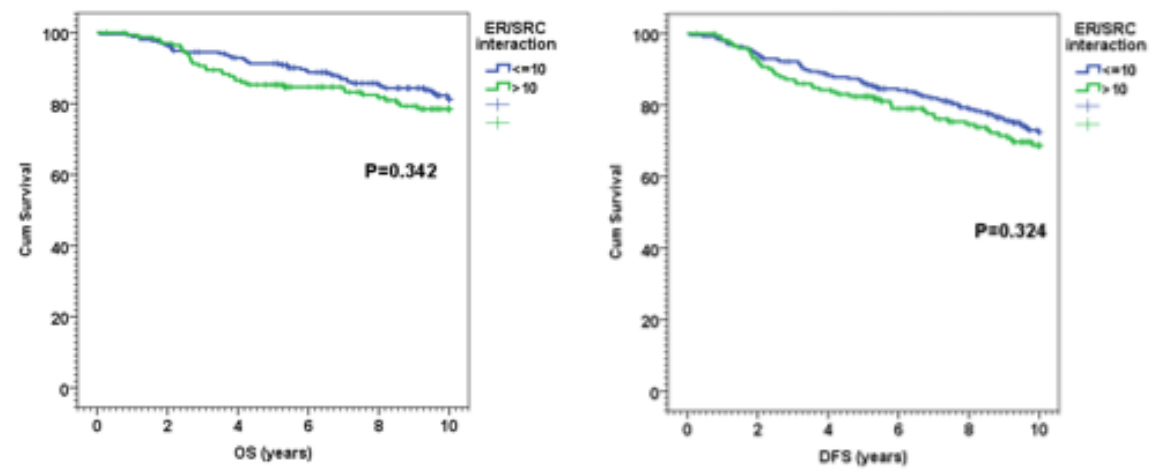

C
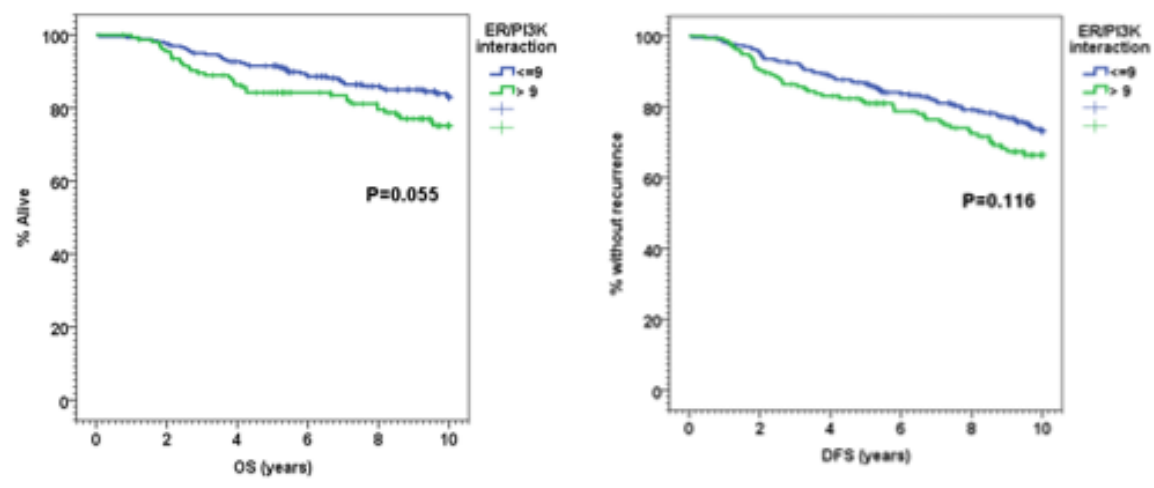

\section{Figure 1}

$\mathrm{ERa} / \mathrm{Src}$ and $\mathrm{ERa} / \mathrm{PI} 3 \mathrm{~K}$ interaction in human tumoral breast samples. a ERa/Src (panels a,b) and $\mathrm{ERa} / \mathrm{PI}$ 3K (panels $\mathrm{c}, \mathrm{d}$ ) interaction were detected by proximity ligation assay (PLA) on two formalin-fixed paraffin-embedded breast tumour sections. The experiments were performed on two serial sections from the same tumour. (Obj X63). b. Kaplan Meier estimates of OS and DFS according to ERa/Src interaction. c. Kaplan Meier estimates of OS and DFS according to ERa/PI3K interaction. 
a

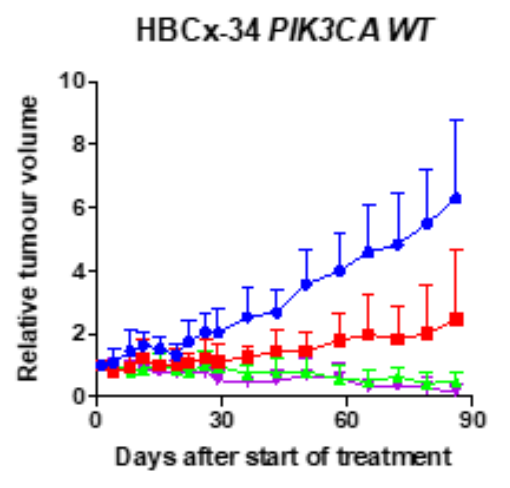

$$
\begin{aligned}
& =\text { Ctr } \\
& =\text { BYL } \\
& =\text { FULV } \\
& =\text { BYL + FULV }
\end{aligned}
$$

C

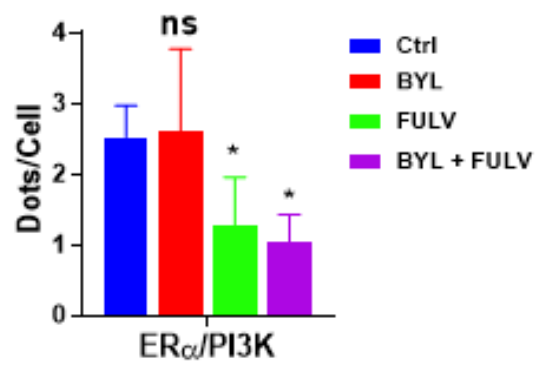

e

$E R \alpha$

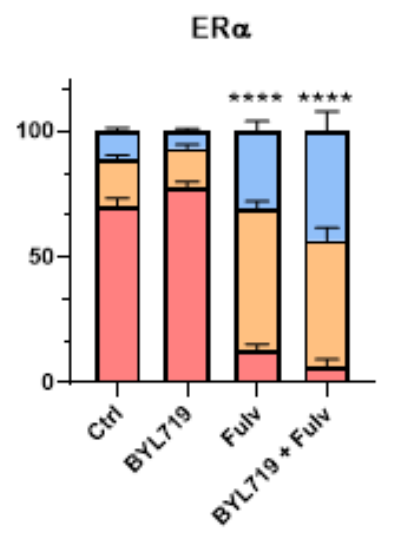

p-S6 b

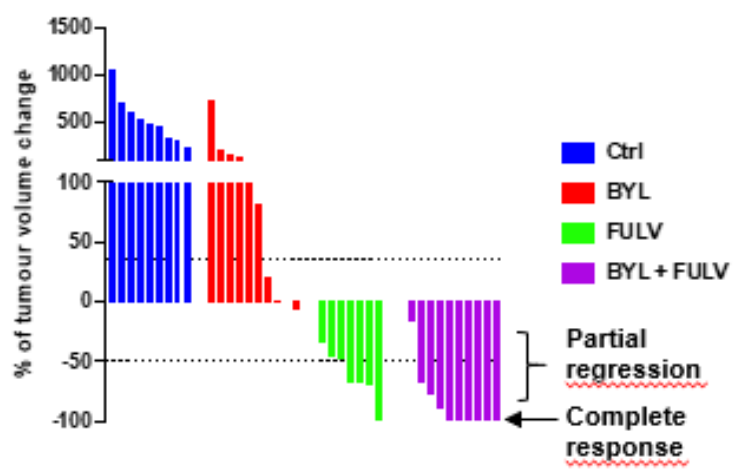

d
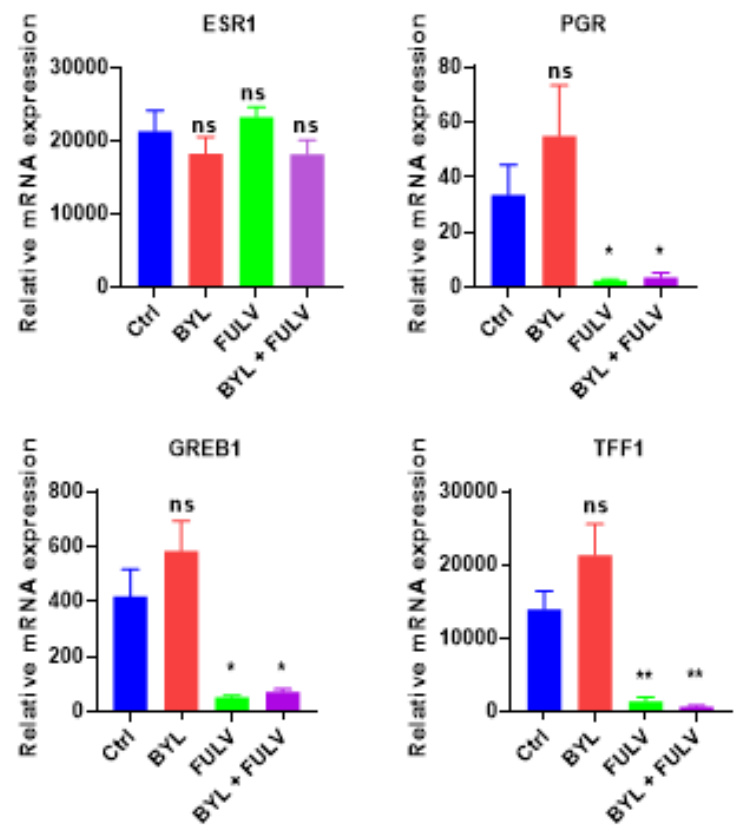

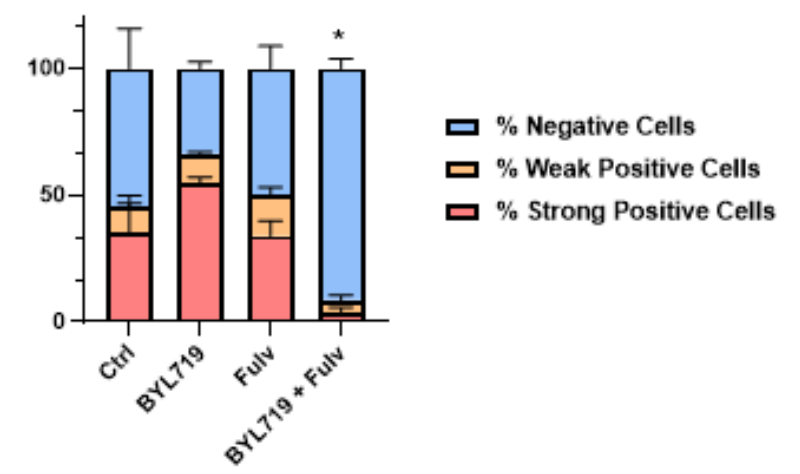

Figure 2

In vivo drug response to BYL719 or fulvestrant alone, and combined in the HBCX-34 PDX model. a Effect of the different treatments on $\mathrm{HBCx}-34$ tumour growth. Each treatment included 10 mice, $y$-axis indicates the mean of RTV +/-SD. b Waterfall plot representing the percent of change in tumour volume from baseline in individual HBCx-34 xenografts in the different treatment groups. c PLA was performed on treated tumours embedded in paraffin to study the interactions between ERa and PI3K. Quantification 
was performed by counting the number of signals per cell in five independent zones of the section ( $n>$ 500 cells counted/tumour). Significance (P-value) between treatments was determined using the Student t-test. ns: non-significant; * $P<0.05 ;{ }^{* \star} P<0.01$. $d$ Expression of estrogen-regulated genes (ERG) analysed by RT-QPCR in PDX tumour samples $(\mathrm{N}=4)$. e IHC staining was performed on formalin-fixed paraffinembedded PDX tumours using anti-ERa, anti-P-AKT (S473) and anti-P-S6 riboprotein (S235/6) antibodies. Quantification of highly, medium and negative cells was performed as described in the method section. Significance ( $P$-value) between treatments and controls were performed using t-test. Only signifancy for strong positive cells was highlighted as * $P<0.05 ; * \star \star \star ~ P<0.0001$. 
a

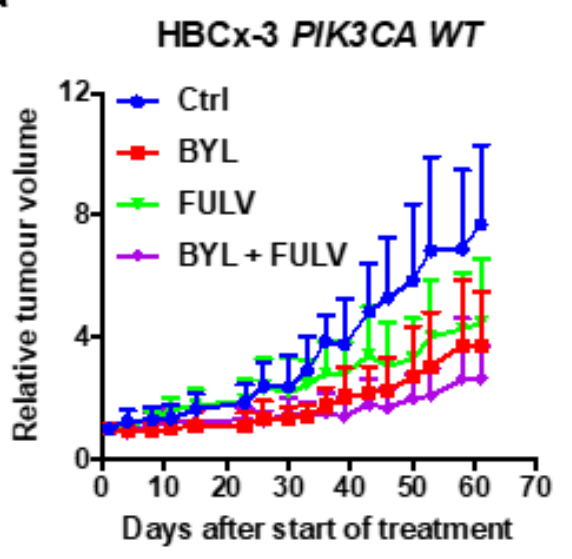

C

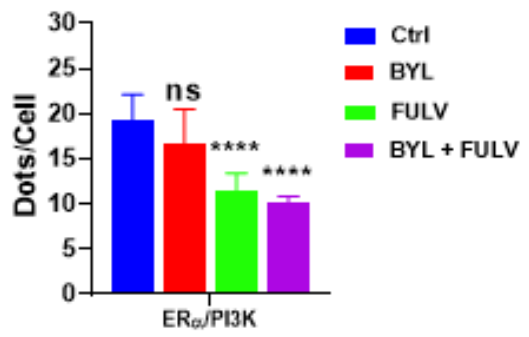

b

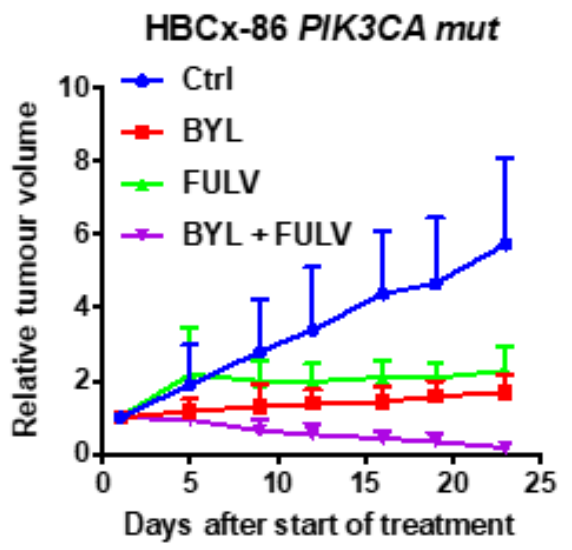

d

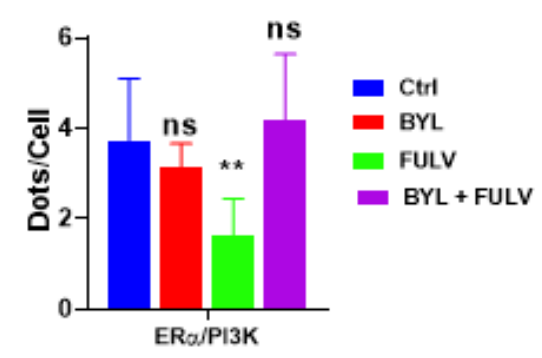

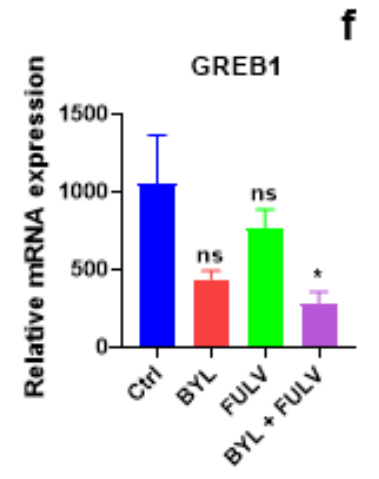
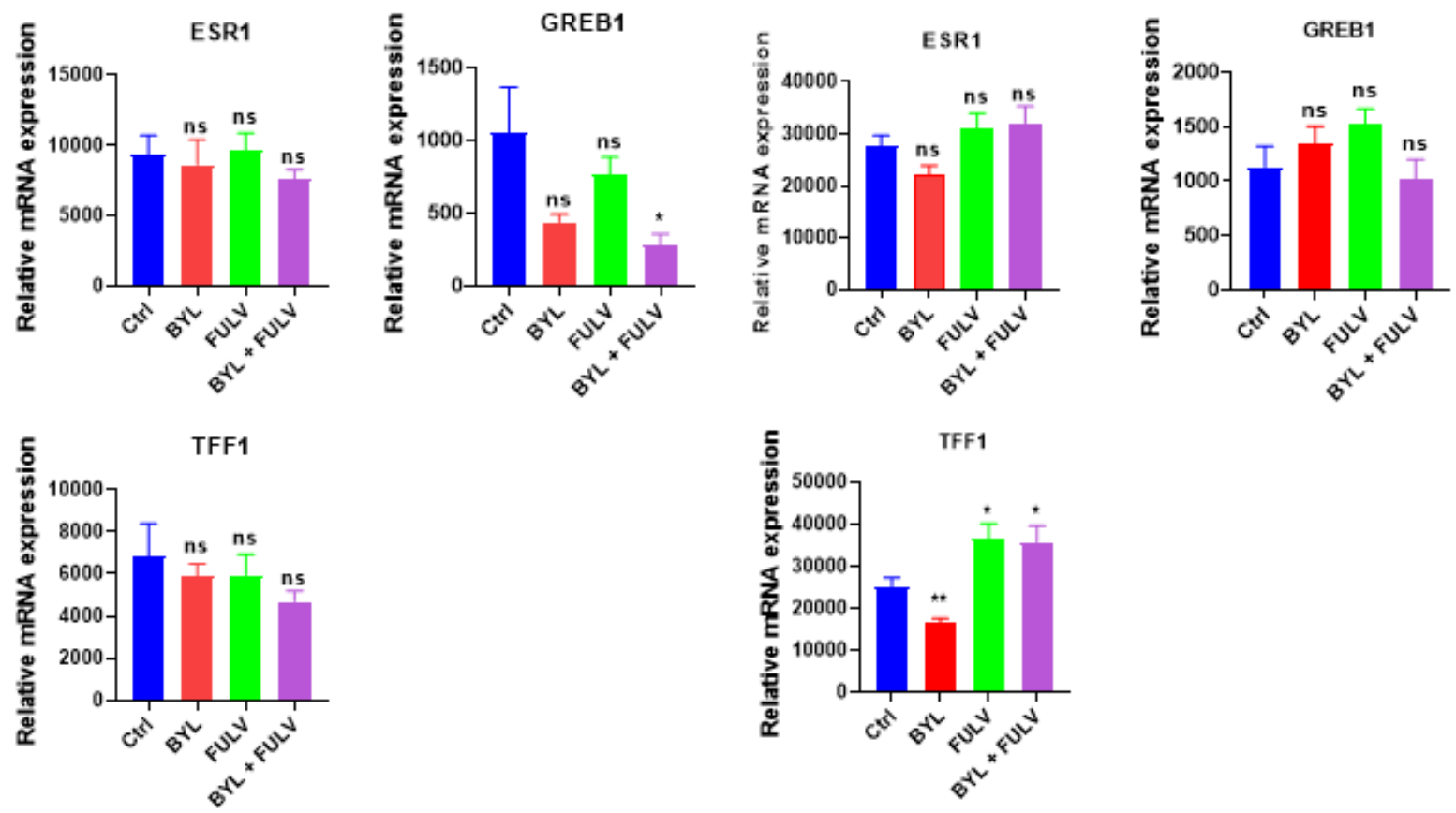

\section{Figure 3}

In vivo drug response to BYL719 or fulvestrant alone, and combined in the HBCX-3 and HBCX-86 PDX models. a Effect of the different treatments on $\mathrm{HBCx}-3$ tumour growth. Each treatment included 10 mice, $y$-axis indicates the mean of RTV +/- SD. b Effect of the different treatments on HBCx-86 tumour growth. c, d PLA was performed and analysed as in Figure 2. ns: non-significant; $* \mathrm{P}<0.5$; $* \star \mathrm{P}<0.01$. e, $\mathrm{f}$ RT-QPCR was performed from RNA extracted from frozen tumour samples using specific primers for ERG. $\mathrm{g}, \mathrm{h}$ IHC 

(S473) and anti-P-S6 riboprotein (S235/6) antibodies. Quantification of highly, medium and negative cells was performed as described in the method section. Significance (P-value) between treatments and controls were performed using t-test. Only signifancy for strong positive cells was highlighted as $\star \star ~ P<$ $0.01, * \star * P<0.001, * \star * \star P<0.0001$.

a HBCx-22 TamR PIK3CA WT

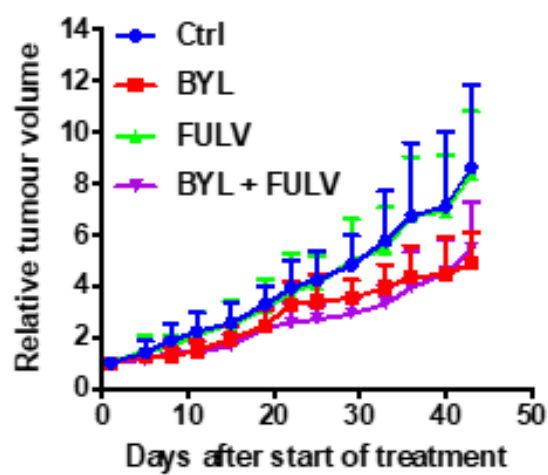

C

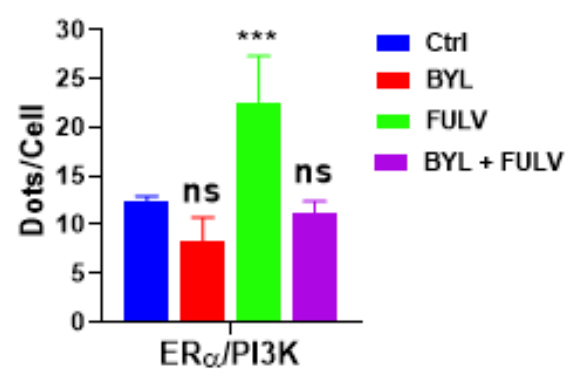

e
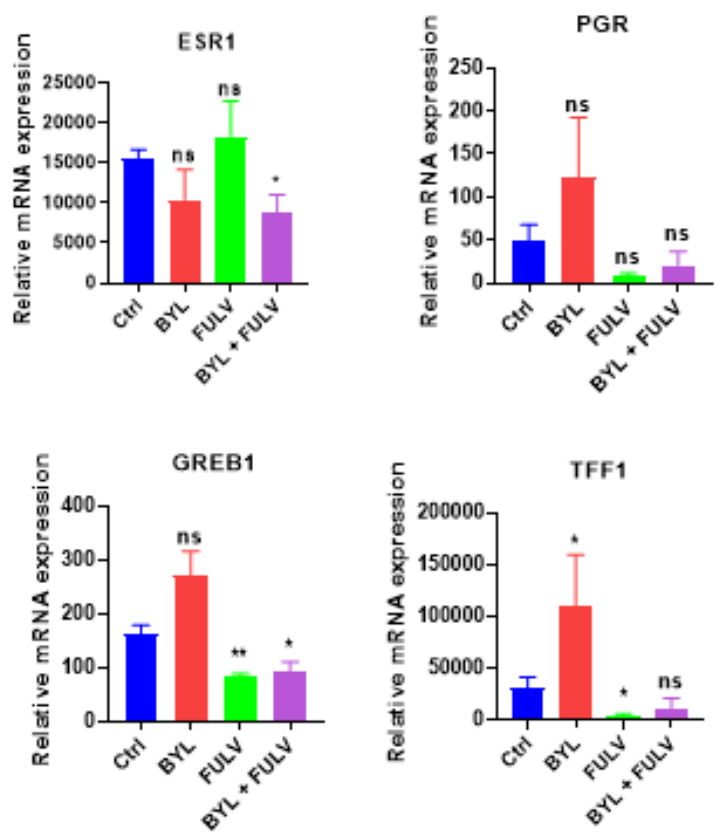

b BC1111 PIK3CA mut

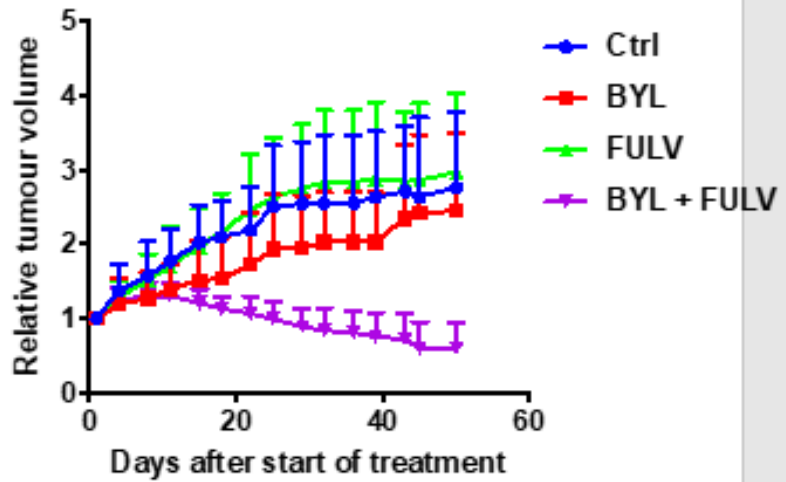

d

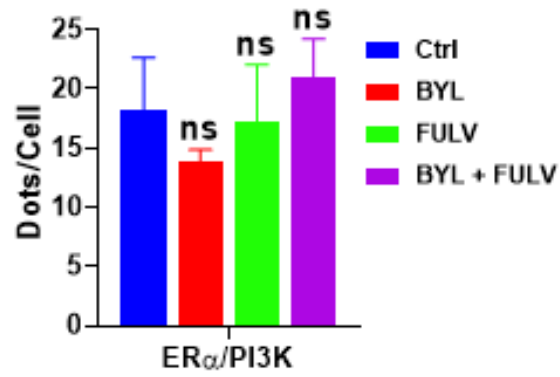

f
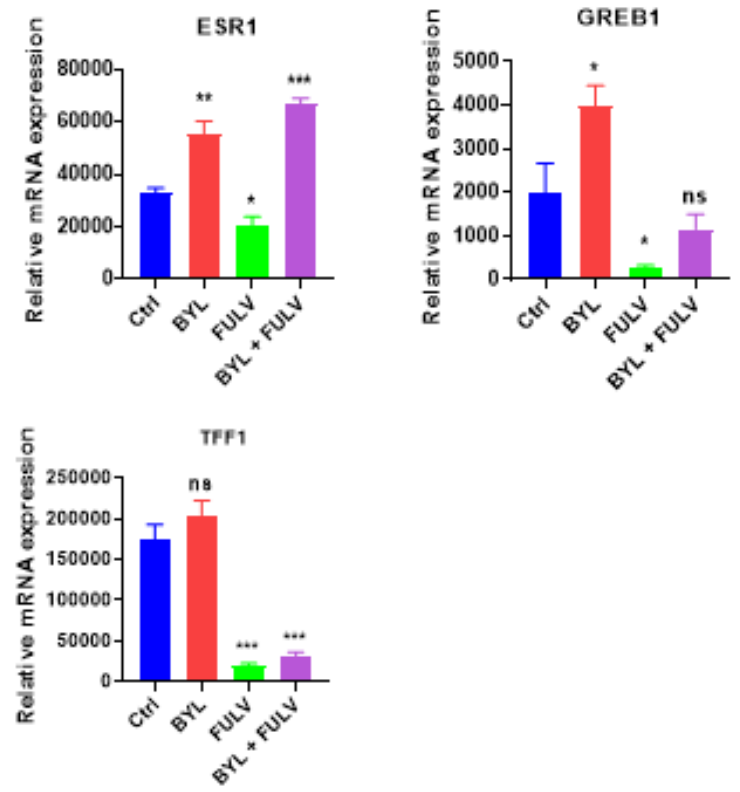

Figure 4 
In vivo drug response to BYL719 or fulvestrant alone, and combined in the HBCX-22 TamR and BC1111 PDX models. a Effect of the different treatments on HBCX-22 TamR tumour growth. Each treatment included 10 mice, $y$-axis indicates the mean of RTV +/-SD. b Effect of the different treatments on HBCx953 tumour growth. c, d PLA was performed and analysed as in Figure 2. e, f RT-QPCR was performed from RNA extracted from frozen tumour samples using specific primers for ERG. $\mathrm{g}, \mathrm{h}$ IHC staining was performed on formalin-fixed paraffin-embedded PDX tumours using anti-ERa, anti-P-AKT (S473) and anti-P-S6 riboprotein (S235/6) antibodies. Quantification of highly, medium and negative cells was performed as described in the method section. Significance (P-value) between treatments and controls were performed using t-test. Only signifancy for strong positive cells was highlighted as * $\mathrm{P}<$ $0.05 ;{ }^{* *} \mathrm{P}<0.01,{ }^{* \star \star *} \mathrm{P}<0.0001$. 
a

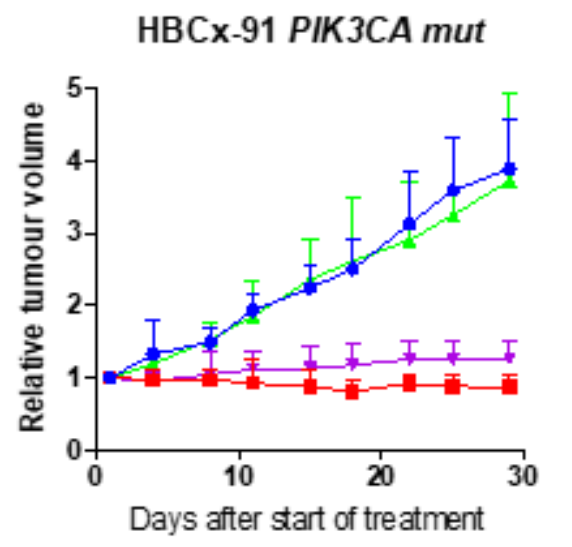

C

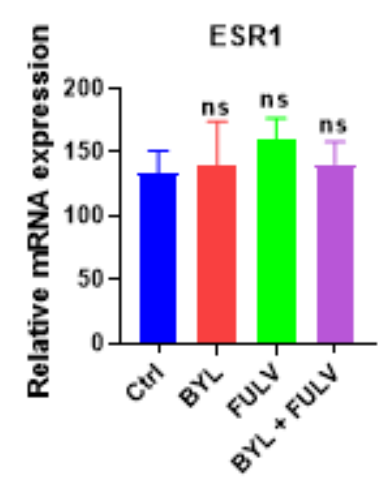

b

$\rightarrow$ Ctrl

$\rightarrow$ BYL

¿ FULV

$\rightarrow$ BYL +FULV

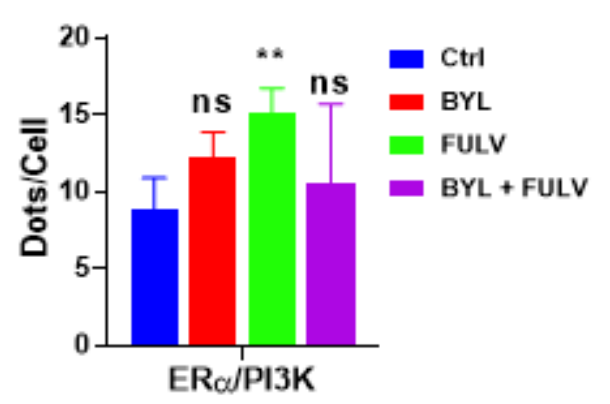

d

$\mathrm{ER} \boldsymbol{\alpha}$
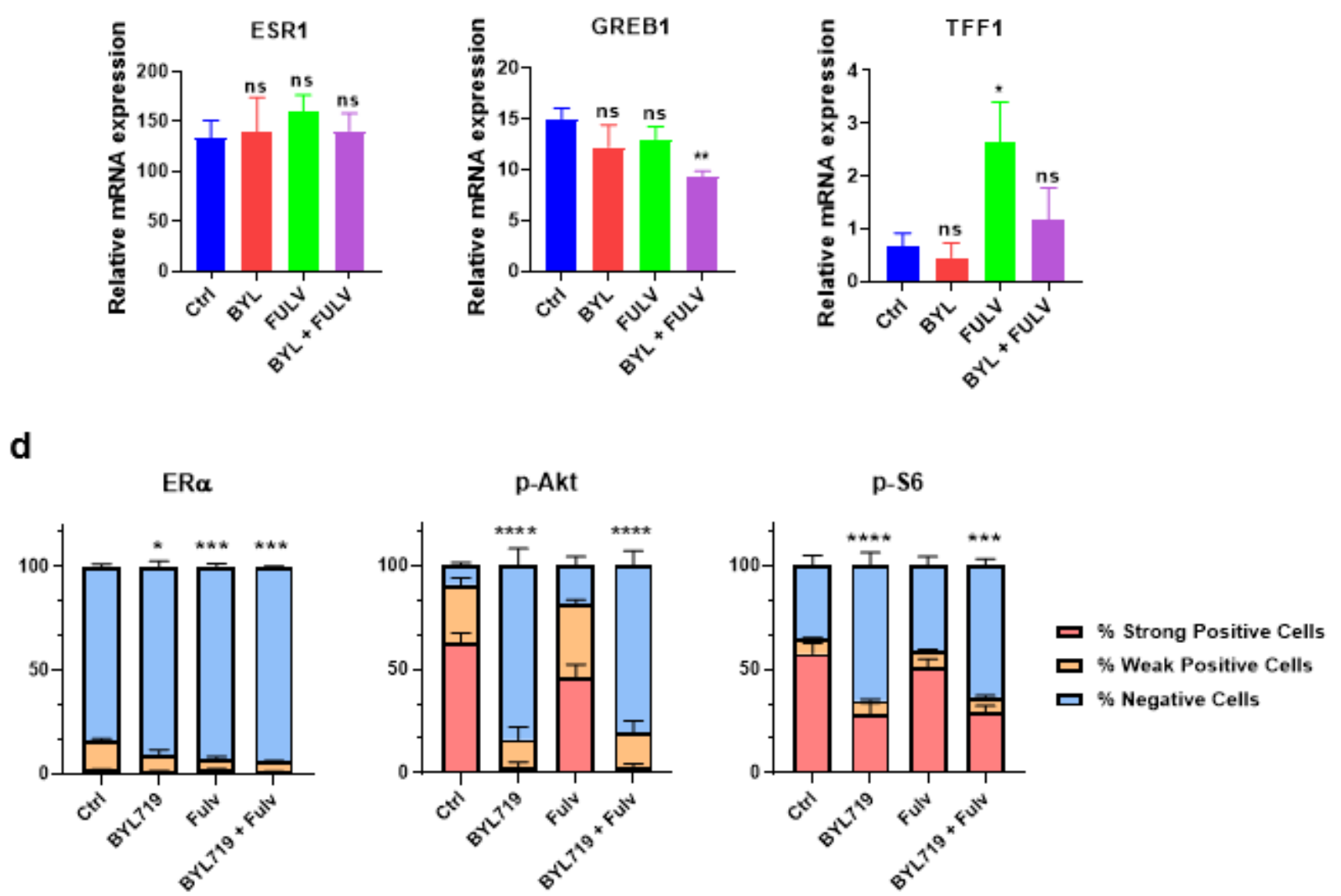

Figure 5

In vivo drug response to BYL719 or fulvestrant alone, and combined in the HBCX-91 PDX model. a Effect of the different treatments on $\mathrm{HBCx}-91$ tumour growth. Each treatment included 10 mice, $y$-axis indicates the mean of RTV +/- SD. b PLA was performed and analysed as in Fig. 2. c RT-QPCR was performed from frozen tumour for ERG expression. d IHC staining was performed on formalin-fixed paraffin-embedded PDX tumours using anti-ERa, anti-P-AKT (S473) and anti-P-S6 riboprotein (S235/6) antibodies.

Quantification of highly, medium and negative cells was performed as described in the method section. 
Significance (P-value) between treatments and controls were performed using t-test. Only signifancy for weak positive cells was highlighted as * $P<0.05$, *** $P<0.001$, **** $P<0.0001$.

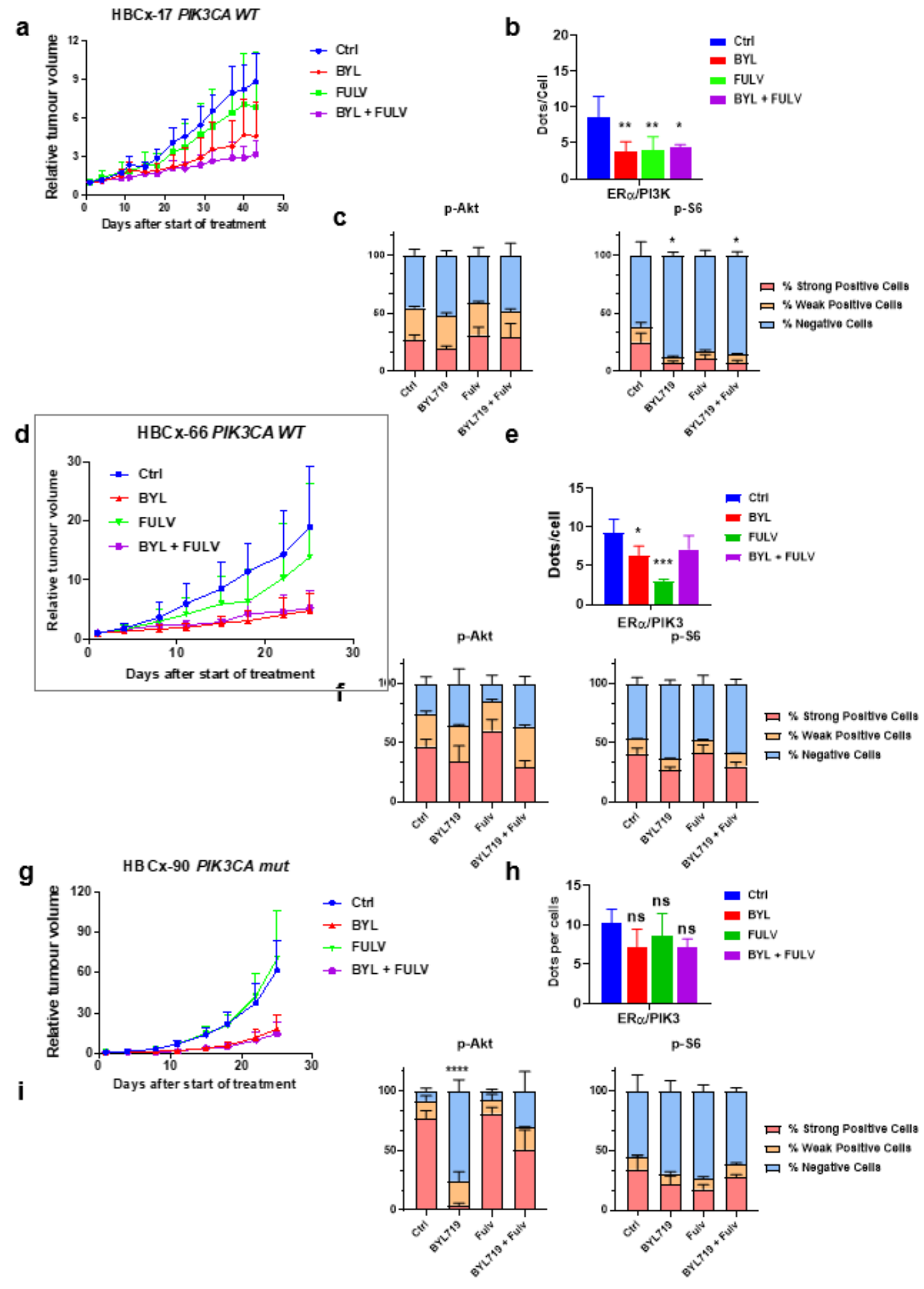

Figure 6

In vivo drug response to fulvestrant, BYL719 alone, and combined in 3 ERa-negative models. a Effect of the different treatments on $\mathrm{HBCx} 27$ tumour growth. Each treatment included 10 mice, $y$-axis indicates the mean of RTV +/- SD. b PLA was performed and analysed as in Fig. 2. c IHC staining was performed on 
formalin-fixed paraffin-embedded PDX tumours using anti-P-S6 riboprotein (S235/6) antibody. d Effect of the different treatments on HBCx-801 tumour growth. Each treatment included 10 mice, y-axis indicates the mean of RTV +/-SD. e PLA was performed and analysed as in Figure 2. $f$ IHC staining was performed on formalin-fixed paraffin-embedded PDX tumours using anti-P-AKT (S473) and anti-P-S6 riboprotein (S235/6) antibodies. g Effect of the different treatments on HBCX-90 tumour growth. Each treatment included 10 mice, $y$-axis indicates the mean of RTV +/-SD. h PLA was performed and analysed as in Fig. 2. i IHC staining was performed on fixed PDX tumours using anti-P-AKT (S473) and anti-P-S6 riboprotein (S235/6) antibodies. Quantification of highly, medium and negative cells was performed as described in the method section. Significance (P-value) between treatments and controls were performed using t-test. Only signifancy for strong positive cells was highlighted as * $P<0.05$,

\section{Supplementary Files}

This is a list of supplementary files associated with this preprint. Click to download.

- additionalfile15Ref.docx

- additionalfile14FigureS11.docx

- additionalfile13Figure10.docx

- additionalfile12FigureS9.docx

- additionalfile11FigureS8.docx

- additionalfile10FigureS7.docx

- additionalfile9FigureS6.docx

- additionalfile8FigureS5.docx

- additionalfile7FigureS4.docx

- additionalfile6FigureS3.docx

- additionalfile5FigureS2.docx

- additionalfile3TableS2.docx

- additionalfile2Tables1.docx

- additionalfile4FigureS1.docx

- additionalfile1suppmethods.docx 